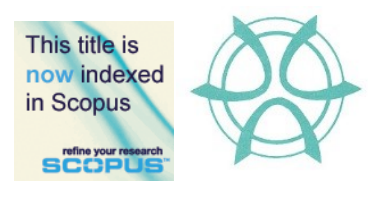

\title{
PURCHASING DECISION OF PROPERTY BUYERS: THE HOUSING QUALITY, FINANCIAL CAPABILITIES, AND GOVERNMENT POLICIES STUDIES
}

\author{
Kenn Jhun Kam ${ }^{1}$, Tze Shwan Lim², Danielle Li Ping Yoong ${ }^{3}$, Fuey Lin Ang ${ }^{4}$, Boon \\ Tik Leong ${ }^{5}$ \\ 1,2,3,4,5 School of Architecture, Building and Design \\ TAYLOR'S UNIVERSITY
}

\begin{abstract}
There are generally three types of house buyers called owner-occupiers, investors, and speculators. However, various factors that affect their decision to purchase a house. The research aims to identify the main factors that will affect the purchase decision of property buyers. Factors such as environmental factors, financial factors, governmental factors, subjective norms, and physical design factors will affect their decision to purchase. The research technique used is quantitative research. Descriptive analysis and inferential analysis to analyse the hypothesis. Based on the findings, the factors that showed to be statistically significant are the environmental, governmental, and subjective norm factors. Environmental factor has a positive influence towards the purchasing decision of dwelling while governmental and subjective norm factor has a negative influence onthe purchasing decision of residential properties. The regression model findings from this research show not only governmentimposed regulation could significantly affecting the purchasers' decision, however, environmental and subjective norm factors play a major role in this matter. This information is beneficial to developers that have the intention to construct dwellings in the future. Developers can take into consideration all the significant factors before deciding on the location for their future development
\end{abstract}

Keywords: purchase decision, house buyers, environmental factors, financial factors, government factors, residential properties, inferential analysis

\footnotetext{
${ }^{1}$ Senior Lecturer at Taylor’s University. Email: kennjhun.kam@taylors.edu.my
} 
PLANNING MALAYSIA

Journal of the Malaysia Institute of Planners (2021)

\section{INTRODUCTION}

The Malaysian government has been putting effort into improving the housing sectors in terms of quantity and quality by providing incentives to the public and private developers. However recently, prices of houses have been shooting high up due to inflation and weakening Ringgit Malaysia while the salary of the household -is increasing at a slower pace. The existing gap between what the developers sell and what the households or individuals can afford is getting further as time goes on Atati (2014).

\section{PROBLEM STATEMENT}

According to Bank Negara Malaysia, BNM (2015), from the last five years, there is a shortfall in the supply of housing as shown from the mismatch between the growth rate of the housing supply and the increasing number of potential households. On average the total number of completed houses are 166,876, and approximately a total of 117,250 household increases simultaneously. Thus, this indicates that there will be a surplus of 49,626 units of houses annually. However, in the year 2010 to 2015 , the completion of the total number of housings has been declining to approximately 80,089 units per year while the net increase of the number of households is on average 166,000 per year. This implies that from the year 2010 to 2015 there is a shortage of 85,911 units of houses (BNM, 2015). As mentioned by Zainun and Ismail $(2015$, p.1037) 'housing supply is not keeping up with demand'.

According to Hong Leong Investment Bank Research (2016), the National Property Information Centre (NAPIC) recorded that there was a drop of $5.7 \%$ in the transactions made in the year 2015. This decline is recorded to be the second-largest drop since the year 2002 which is placed after the drop that took place in 2009 of a percentage of 8.3. The surplus supply of houses is still on the inclining slope. In the year 2015, the supply of housing stocks has reached a total of 892,000 which is an increase of an additional $16 \%$ since 2004 . This is the highest amount which is overall $18 \%$ of the existing stocks in Malaysia.

\section{RESEARCH AIM AND HYPOTHESIS}

The aim of this study is to understand which factors will affect the purchasing decision of dwellings among property buyers.

Hypothesis 1: Factors that affects the purchasing decision of residential properties among property buyers

H1a: Environmental factors will have a positive relationship with the purchasing decision of residential properties

$H 1 b$ : Financial factors will have a negative relationship with the purchasing decision of residential properties 
K.J. Kam, T.S. Lim, D.L.P. Yoong, F.L. Ang, B.T. Leong

Purchasing Decision of Property Buyers: The Housing Quality, Financial Capabilities, and Government Policies Studies

H1c: Governmental factors will have a negative relationship with the purchasing decision of residential properties

H1d: Subjective norm factors will have a positive relationship with the purchasing decision of residential properties

Hle: Physical design factors will have a positive relationship with the purchasing decision of residential properties

\section{LITERATURE REVIEW}

The decision of purchasing a house is complex and must into consideration a handful of factors as eventually will lead to long-term financial burdens such as a mortgage, day-to-day activities as well as social interaction, security and safety, and many more other factors (Litman, 2012).

\section{Environmental Factor}

Anuar and Muhamadan (2018) emphasized that the three main factors that a person should consider before purchasing a house are location, location, and location, especially the demand on the complete neighborhood facilities. Past researchers have identified the location as one of the main factors that will affect the purchase decision of homebuyers in countries such as Australia, the UK, and Ireland (Daly et al., 2003). Location factor can be commonly linked to the distance and convenience to local amenities such as public transport, health care center and etc (Tobi, Fathi \& Amaratunga, 2018). Proximities will have a significant influence on choosing whether which residential property (Saw \& Tan, 2014).

Neighborhood can be defined as a space whereby a community dwells together with similar interest (Choguill, 2008). Households will prefer to incur additional money for a dwelling that is in a good neighborhood with excellent indoor and outdoor qualities (Aini et al., 2017). Some of neighboring environment qualities such as the pollution level, crime, and safety level, and cleanliness are vital and will eventually affect the purchasing decision of the buyers (Tan, 2011a). Khalid et al. (2020) conducted research and proved that a gated community lowers the chances of any unwanted crime.

\section{Financial Factor}

Price can be defined as a type of payment where one party pays the other for their services or transactions done. In real estate, the price is set bythe developers after doing relevant research in the market. According to Shinde, Gawande (2018) the price of residential properties is one of the factors to drive the demand of investors. Lower price dwellings will encourage more prospective buyers to purchase dwellings (Humphrey \& Verdery, 2020). Fluctuation of the price of these dwelling is also affected by a set of factors such as exterior and interior or the dwell, location, facilities and many more (Rahadi et al., 2013). 
According to Paramesran (2013), the banking systems in Malaysia have vied with one another to promote various types of loans that can be adjusted to suit their preference and thus increasing the demand and eventually the price of the houses. The financing sourcing from the housing sector is inclined by a compound annual growth rate (CAGR) of $10.6 \%$ from the year 1997 to 2012. In 1997, there was a total of RM 20.5 billion loans and it has increased to RM 95.2 billion by 2012 which is four times the amount in 1997 (Zandi et al., 2015). Kam et al. (2016) reported that the ability to widen the availability of these loans from the financial institutions depends on the supply of new housing. However, in the event when the government imposes stringent housing regulations, the demand for houses will decline as people will be unable to take long-term loans to purchase a house.

Interest rates are the cost of borrowing a loan or mortgage from a financial institution (Fields, 2018). It is a vital factor to determine how much to pay back with having a property or house. According to Chang et al. (2019), at the time when interest rates decline, it is very tempting to purchase a house. This is provided if the rates are reduced due to the weakened economic growth with other factors remaining, the prices of the house would not incline. Pembina Institute (2013) further supports that a low-interest rate for a mortgage would drive the demand for houses but if the supply of new units does not keep up, the price of the houses will eventually increase and would discourage people to purchase a house.

\section{Governmental Factor}

Real Property Gain Tax (RPGT) is the type of payment or charge originating from the disposal of the real properties and shares in those companies for real properties located in Malaysia. It is computed based on the money that is to be made by subtracting the disposal price and acquisition price (Geoffrey, 2014). From the Ministry of Finance (MOF) Malaysia stated that the tax imposed is based on the holding period of the property before selling it. The tax is associated with other costs such as professional fees, stamp duty, etc. (Zainuddin, 2015)

Developer Interest Bearing Scheme (DIBS), whereby the interest rates for the housing loan incurred during the construction phase will be absorbed by the developers. The result of this scheme is that is not necessary for the purchasers to cough out with other payment than the initial deposit during the period of construction (Paramesran, 2013). Since purchasers are still required to pay for the initial deposit, thus this is not a Build-Then-Sell (BTS) concept but a Sell-ThenBuild (STB) concept. The initial cost that is to be incurred by the purchaser could be hefty as the cost comprises not only the down payment when the Sale and Purchase Agreement (S\&P) is signed but as well as other costs (REHDA, 2014).

The Malaysia Government has been implementing various housing policies and housing programmes through various Malaysia Plans. The housing 
K.J. Kam, T.S. Lim, D.L.P. Yoong, F.L. Ang, B.T. Leong

Purchasing Decision of Property Buyers: The Housing Quality, Financial Capabilities, and Government Policies Studies

policies introduced by the Malaysian Government was to provide more attention to the production and transportation of the houses through the participation of the private sectors.

\section{Subjective Norm Factor}

Tonglet et al (2004) defined subjective norm as to how an individual would allow or control the pressures put on him or her to do or not to do. Housing preferences are determined by many other factors such as religion, social status and relation, and many more (Jabareen, 2005). Social pressures such as influence from people surrounding one's everyday life, family members, friends, and acquaintance, or sometimes agents will affect the property buyer's perception on deciding what or whether to buy or not (Kam et al. 2018). For example, the perception of an individual may be affected by the persuasion from their family, or incentives offered by the government and thus opt to purchase a certain type of house. One of the most influential party is often to be one family members (Teoh, 2011). Research in the United States shows that spouse and children carry the highest influential level that will affect one's purchase decision for a dwell (Livette, 2007). It was further elaborated that among these two parties, children carry a high impact as adults would normally provide the best for their children.

\section{Physical Design Factor}

The physical design includes design, physical conditions, and the quality of the property. Based on Hurtubia et al. (2010), the features of a house such as the number of rooms and bathrooms would be considered first before deciding on purchasing, this is especially in western countries. The size of the living and dining hall, usable area of the house, and number of rooms are all considered under design factors (Tan, 2012). The purpose of purchasing residential properties affects the type of house to purchase. For example, purchasing a property to live in and purchasing as an investment has a significant difference. Speculators prefer buying smaller units in high-rise buildings as they tend to sell better later on (Kohler, 2013). Other design factors such as good ventilation and good lighting also contribute to the purchase decision of an individual (Sew \& Chin, 2000).

\section{RESEARCH METHODOLOGY}

A research framework is developed in this research study based on the objective of this research study by having 5 factors and 28 items, as shown in Table 1 below. 
PLANNING MALAYSIA

Journal of the Malaysia Institute of Planners (2021)

Table 1: Items of the Factors Affecting Purchasing Decision of Residential Properties

\begin{tabular}{|l|l|}
\hline Factors & Items \\
\hline Environmental Factor & E1) Existence of shopping malls and food courts \\
& E2) Distance to workplace \\
& E3) Availability of local amenities \\
& E4) Existence of public transport \\
& E5) Safety/crime rate \\
& E6) Cleanliness of surroundings \\
& E7) Status level of neighbors \\
& E8) Noise level of surroundings \\
\hline Financial Factor & F1) Price of house \\
& F2) Affordability \\
& F3) Ease to take a loan from banks \\
& F4) Time is taken to pay back the loan \\
& F5) Interest rates of loans \\
\hline Governmental Factor & G1) Reinstatement of DIBS \\
& G2) Implementation of RPGT \\
& G3) Government housing schemes and policies \\
\hline Subjective Norm Factor & S1) Permit suggestions from others \\
& S2) Influence from parents \\
& S3) Influence from friends \\
\hline S4) Influence from family members & S5) Influence from property agents \\
\hline Physical Design Factor & P1) Size of living room \\
& P2) Size of bedroom \\
& P3) Number of bedrooms and bathrooms \\
& P4) Size of compound \\
& P5) Size of kitchen and dining \\
& P6) Interior and exterior layout and design of \\
& house \\
& P7) "Feng Shui" of the house \\
\hline
\end{tabular}

\section{Research Technique}

This method emphasizes the statistical, mathematical, and numerical types of analysing the data compiled from various methods such as surveys and questionnaires. It puts it main focus on collecting numbers for its data and using it across different people to explain a particular occurrence (Babbie, 2010). A self-administrated questionnaire was used for this research. There are two broad categories of the format used in questionnaires which are the open ended or closed questions (Neuman, 2010). However, in this questionnaire, only closed questions were used to answer the objectives of this research. All questions were asked based on scale-response questions which is the Likert Scale. The questionnaire designed for this research study is divided into three sections where Section A is 
K.J. Kam, T.S. Lim, D.L.P. Yoong, F.L. Ang, B.T. Leong

Purchasing Decision of Property Buyers: The Housing Quality, Financial Capabilities, and Government Policies Studies

the demographic profile of the respondents and Section B is the factors affecting the purchasing decision of residential properties among the respondents.

The research topic is to study the factors affecting the purchasing decision of residential property among property buyers. Since property buyers can be anyone of legal age and can purchase a property, thus the scope of this research will be on people living in Klang Valley which is one of the most urbanized places located in Malaysia. To have an equal and fair chance for every respondent of the population, a simple random sampling method is used in the study. Further from that, the snowball sampling method which is one of the nonprobability sampling methods is also used to enhance the respondents' rate to get the statistic normality of the respondents achieve for a more significant statistic analysis output.

\section{Method of Analysis}

According to Zikmund et al. (2010), descriptive analysis is a method of presenting the data in a method that describes the characteristics of a population or sample. This type of analysis is commonly used to present the demographic profile of the respondents. There are various ways to present the data, one of the popular methods is by using the frequency charts either pie or bar. It is relatively simple to understand the charts at a glance. Frequency can be defined as the total number of respondents that answered for each category of choice. The frequency can be converted into a percentage to suit the data collected.

The average index method is used to calculate the mean of an item by multiplying the frequency by a weightage. This method of analysis is employed to rank the factors that affect the purchasing decision based on the level of importance that is measured using the Likert scale.

Logistic regression is used to test models to forecast the outcomes with binary options. The dependent variable in the hypothesis is the purchasing decision of residential property which is asked in the questionnaire as a binary question "Have purchased" and "Have not purchased". The independent variable on the other hand could be either be categorical or continuous data (Pallant, 2002). The independent variables which are the factors in this research are measured using Likert scales which are continuous.

\section{DATA ANALYSIS}

A total of 5,000 emails with the survey web link attached were sent out and a total of 386 surveys were filled in through google form. However, as this research only focus on respondents living in Klang Valley, the response was filtered and hence only an usable survey of 348 number of response is used for this research. 
PLANNING MALAYSIA

Journal of the Malaysia Institute of Planners (2021)

\section{Average Index Ranking}

Table 2 presents the mean or average index of five (5) factors that affect the purchasing decision of residential properties in Klang Valley. It is notable that from the table, the top 5 items that affect the purchasing decision of residential properties are the items for financial and environmental factors. The maximum score for each factor is five (5) with the selection of "Very Important" while the minimum score is one (1) with the choice of "Not Important".

Table 2: The average index of each factor and its ranking

\begin{tabular}{|c|c|c|c|}
\hline \multicolumn{2}{|c|}{$\begin{array}{l}\text { Factors Affecting Purchase Decision of Residential } \\
\text { Properties }\end{array}$} & Mean & Ranking \\
\hline F1 & $\begin{array}{l}\text { I would consider the price of the house before I } \\
\text { purchase a residential property }\end{array}$ & 4.8145 & 1 \\
\hline $\mathrm{F} 2$ & $\begin{array}{l}\text { I would consider the affordability of the residential } \\
\text { property before I purchase it. }\end{array}$ & 4.8024 & 2 \\
\hline E5 & $\begin{array}{l}\text { I would take into consideration the safety/crime rate } \\
\text { of the area when I purchase a residential property }\end{array}$ & 4.7581 & 3 \\
\hline E2 & $\begin{array}{l}\text { I would look at the distance to my workplace when I } \\
\text { purchase a residential property }\end{array}$ & 4.5605 & 4 \\
\hline $\mathrm{F} 4$ & $\begin{array}{l}\text { I would consider the time taken to pay back the loan } \\
\text { before I purchase a residential property }\end{array}$ & 4.5000 & 5 \\
\hline
\end{tabular}

The price of a residential property is vital in determining whether or not one should purchase the property. This result is supported by Shinde, Gawande (2018), who mentioned that price is one of the main factors that drive the demand of purchasers. In Malaysia, the price index for houses has been increasing. As reported by BNM (2015), there is on 21 percent of residential properties have been launched at a price below RM 250,000.00 while residential properties at a price RM 500,000.00 are abundant in the market. This shows that the price of residential properties has a great effect on the purchasing decision for buyers.

Hickman et al. (2017) also stated that residential properties with lower prices will encourage more buyers to purchase residential properties as the property is said to be more affordable. The surplus of residential property that is not affordable tends to form part of the housing overhang problem in Malaysia. Housing affordability in Malaysia has been an issue that concerns everyone especially the Millennials who are people born in the early 1980s to 2000s.

The safety and crime rate of the surroundings is also an essential factor that will affect the purchase decision of buyers. This finding matches the statement made by Abdullah et al. (2020), who mentioned that household tends to voluntarily incur additional expenses such as having security guards on shift 
K.J. Kam, T.S. Lim, D.L.P. Yoong, F.L. Ang, B.T. Leong

Purchasing Decision of Property Buyers: The Housing Quality, Financial Capabilities, and Government Policies Studies

for twenty-four (24) hours to guard the safety of the residents. This service can be commonly found in gated communities.

Placing fourth is the distance of workplace that affects the purchasing decision of the purchasers. Distance to work is one of the locational factors that has the most significant influence onselecting the correct residential property. This finding aligns with Karsten (2007) who reported that individuals who prefer to spend the minimum time to travel to their workplace tend to purchase a dwelling near their workplace. It is almost impossible to purchase a dwelling without making any long-term loans from financial institutions. Thus, it is the concern of many on the period that is needed to repay the loan to the financial institutions. Different financial institutions offer different mortgage loans with different repayment periods and interest rates (BLR) to suit the borrowers.

\section{Logistic Regression}

Table 3: Logistic Regression Results based on constructs

\begin{tabular}{|c|c|c|c|c|}
\hline \multicolumn{2}{|c|}{ Variable } & B-value & Wald & Significance \\
\hline \multicolumn{5}{|c|}{ Dependent } \\
\hline \multicolumn{5}{|c|}{ Purchased a house (No/Yes) } \\
\hline \multicolumn{5}{|c|}{ Independent } \\
\hline 1 & Environmental Factors & 1.128 & 8.042 & 0.005 \\
\hline 2 & Financial Factors & 0.139 & 0.166 & 0.684 \\
\hline 3 & Governmental Factors & -0.548 & 9.753 & 0.002 \\
\hline 4 & Subjective Norms Factors & -0.512 & 6.172 & 0.013 \\
\hline 5 & Physical Design Factors & 0.131 & 0.256 & 0.613 \\
\hline
\end{tabular}

All items for each factor were computed into a construct to test against the dependent variable. Based on Table 3, it is shown that only three (3) constructs are proved to be statistically significant that has a p-value of less than 0.050 . The three constructs are an environmental factor, governmental factor, and subjective norm factor. The coefficient or B-value of the predictor is 1.128 that indicates that there is an existence of a positive relationship between the environmental factor and the purchasing decision of residential properties. This can be interpreted as for every increase in score for the importance of the environmental factors, the likely hood that they have purchased a house increases by 1.128. This finding aligns with Tobi, Fathi \& Amaratunga, 2018, who state that the distance and convenience to nearby amenities would greatly affect the purchasing decision of dwellings. Thus, respondents that choose the distance to local amenities as important when they are considering to purchase a house, would have purchased a house. The hypothesis is accepted.

The overall model for the governmental factor has a p-value of $0.002<0.050$ and a B-value of negative 0.548 . It can be said that with a coefficient predictor of -0.548 , it indicates that there is a negative influence between 
governmental factors and purchasing decisions. Housing schemes and policies introduced by the Government are mainly for the Generation Y who are currently are facing homeownership issue as the prices of houses these days is very unaffordable towards them. Thus, these schemes are important to aid them to have their own dwelling (Zainun \& Ismail, 2015). The hypothesis is accepted.

The subjective norm factor achieved a p-value of $0.013<0.050$ and a Bvalue of negative 0.512 . It can be said that with a coefficient predictor of -0.512 , it indicates that there is a negative influence between subjective norm factors and purchasing decisions. Teoh (2011) explained that parents are often one of the most influencing parties when purchasing a product. This could be because respondents who are affected by parents are individuals who still live with their parents and are under their parents' influence before making any decisions. The hypothesis is rejected.

\section{CONCLUSION}

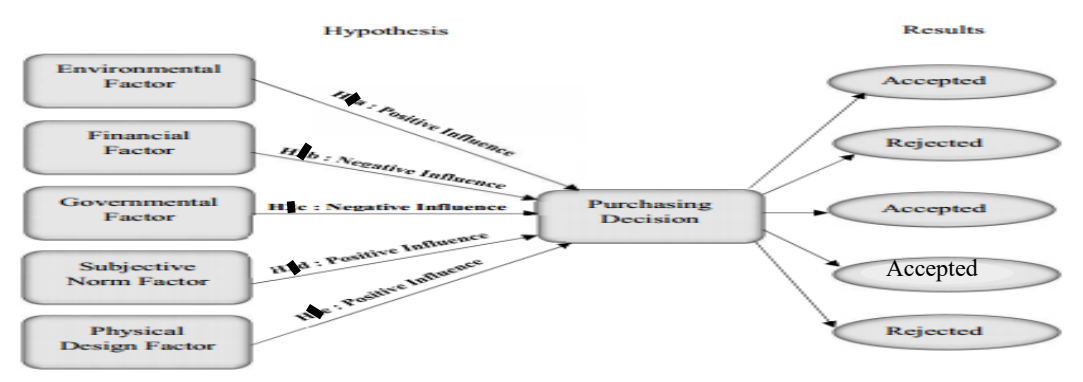

Figure 1: The summary of the findings for the hypothesis.

From the Regression model summary, refer to Figure 1, it can be concluded that three (3) of the hypotheses were accepted and only two (2) were rejected. Three (3) were proven to be statistically significant, which are the environmental, governmental, and subjective norm factors against the purchasing decision while the other two (2) were proven to be not statistically significant. Environmental factors such as distance of local amenities such as schools and hospitals, degree of cleanliness of the neighborhood and the status level of their surroundings influence their purchasing decision. Other than that, governmental factors such as housing schemes implemented by the government affect the lower and middleincome group as the schemes are mainly targeted towards these two groups of income. Subjective Norm factor such as influence from parents also has a significant influence towards the property buyers. Regardless of their age, people still consider advice or comments from their parents before considering purchasing a dwelling. Interestingly, the Financial factor does not play a role in 
affecting the purchaser in their decision on buying a house because according to Shinde, Gawande (2018), the Financial factor has a lesser relationship in the purchaser decision because since the mortgage's loan to Value (LTV) Ratio is up to $70 \%$ for a borrower. Where in another word, a borrower can easily get a loan, which this phenomenon causes the logistic regression of the Financial factors tend to be non-significant in the hypothesis testing. The findings from this research are beneficial to developers that have the intention to construct dwellings in the future. Developers can take into consideration all the significant factors before deciding on the location for their future development. Governmental bodies shall take note of the importance of the housing schemes towards the low and middle-income group as it greatly affects their purchasing decision and aid in promoting homeownership.

\section{REFERENCES}

Abdullah, J., Rashid, K. A., Shah, M. I. B., Leh, O. L. H., Majid, R. A., \& Ngah, R. (2020). Land use development and ridership at Kelana Jaya lrt line, Malaysia. Planning Malaysia Journal of the Malaysian Institute of Planners, 18(4), 220-238.

Aini, A. M., Azriyati, W. N., Aziz, W. A., \& Zulkifli, N. F. (2017). Middle Adults' Housing Expectations for Old-age: A Study of Urban Area of Greater Kuala Lumpur. Journal of Design and Built Environment, 150-165.

Anuar, A. N. A., \& Muhamadan, N. H. (2018). The demand of recreational facilities in neighbourhood parks: Visitors' perspectives. Planning Malaysia Journal of the Malaysian Institute of Planners, 16(3), 197-207.

Atati, F.O. (2014). An investigation into the factors that influence housing finance in developing countries: A case study of Kenya. Bachelor of Degree of Real Estate. University of Nairobi, Kenya.

Babbie, Earl R. The Practice of Social Research. 12th ed. Belmont, CA: Wadsworth Cengage, (2010). Muijs, Daniel. Doing Quantitative Research in Education with SPSS. 2nd edition. London: SAGE Publications, 2010.

Bank Negara Malaysia (2015) Assessing demand-supply conditions in the Malaysian property market. Available From: http://www.bnm.gov.my/files/publication/ar/en/2015/cp01_002_box.pdf [Accessed: 10 May 2016]

Bank Negara Malaysia (2016a). Monthly Statistical Bulletin Jan 2016. Available at: http://www.bnm.gov.my/index.php?ch=en publication catalogue\&pg=en publi cation_msb\&eId=box $1 \& \mathrm{mth}=1 \& \mathrm{yr}=2016 \&$ lang=en [Accessed 20 June 2016]

Chang, Y. F., Choong, W. C., Looi, S. Y., Pan, W. Y., \& Goh, H. L. (2019). Analysis of housing prices in Petaling district, Malaysia using functional relationship model. International Journal of Housing Markets and Analysis.

Choguill, C.L. (2008). Developing sustainable neighbourhoods. Habitat International, $32,41-8$.

Daly, J., Gronow, S., Jenkins, D., \& Plimmer, F. (2003). Consumer behaviour in the valuation of residential property: A comparative study in the UK, Ireland and Australia. Property Management, 21(5), 295-314. 
Fields, D. (2018). Constructing a new asset class: Property-led financial accumulation after the crisis. Economic Geography, 94(2), 118-140.

Geoffrey (2014). Real Property Gain Tax (RPGT) in Malaysia. Available at: http://www.nbc.com.my/blog/real-property-gain-tax-rpgt-in-malaysia/ [Accessed on 26 June 2016]

Hickman, R., Cao, M., Mella Lira, B., Fillone, A., \& Bienvenido Biona, J. (2017). Understanding Capabilities, Functionings and Travel in High- and Low-Income Neighbourhoods in Manila. Social Inclusion, 5(4), 161.

Hong Leong Investment Bank Research (2016) Malaysia's 2015 property market records decline in transaction value, volume. The Edge Property, Available From: http://www.theedgeproperty.com.my/tags/bank-negara [Accessed: 4 May 2016].

Humphrey, C., \& Verdery, K. (Eds.). (2020). Property in question: value transformation in the global economy. Routledge.

Hurtubia, B., Gallay, O., \& Bielaire, M. (2010). Attributes of household, locations and real estate for land use modeling. Sustain City Working Paper, 2.7. Lausanne: EPFL.

Jabareen, Y. (2005). Culture and Housing Preferences in a Developing City. Environment and Behavior, 37(1), 134146. doi: 10.1177/0013916504267640

Jacobsen, D. H. and Naug, B. (2004). What drive house prices? Economic Bulletin, 4(4), 229- 235

Kam, K. J., Chuah, S. Y., Lim, T. S., \& Lin Ang, F. (2016). Modelling of property market: The structural and locational attributes towards Malaysian properties. Pacific Rim Property Research Journal, 22(3), 203-216.

Kam, K. J., Lim, A. S. H., Al-Obaidi, K. M., \& Lim, T. S. (2018). Evaluating housing needs and preferences of generation $\mathrm{Y}$ in Malaysia. Planning Practice \& Research, 33(2), 172-185.

Karsten, L. (2007). Housing as a way of life: Towards an understanding of middle-class families' preference for an urban residential location. Housing Studies, 22(1), 8398.

Khalid, H. A., Ling, O. H. L., Jalil, N. I. R., \& Marzukhi, M. A. (2020). An analysis of the needs of elderly-friendly neighbourhood in Malaysia: Perspectives of older and younger groups. Planning Malaysia Journal of the Malaysian Institute of Planners, 18(4), 144-157.

Kohler, M. J. (2013). Why you should be investing your money in real estate. Entrepreneur. Available from: http://www.entrepreneur.com/article/228506. [Accessed on 10 September 2016]

Livette, M. (2007). Influencer and other "buying" roles in the decision-making process of retirement housing purchasers, Property management, 25(3), 242-256.

Litman, T. (2012). Victoria transport policy Institute. Home Location Preferences and Their Implications for Smart Growth. Available from: www.vtpi.org [Accessed on 12 September 2016].

Neuman, Lawrence. W. (2010). Social Research Methods, Qualitative and 219 Quantitative Approaches (7th ed.). USA: Pearson Education, Inc.

Pallant, J. 2002. SPSS SURVIVAL MANUAL-A step by step guide to data analysis using SPSS for Windows (Version 12). Allen Unwin, New South Wales. p 121 
K.J. Kam, T.S. Lim, D.L.P. Yoong, F.L. Ang, B.T. Leong

Purchasing Decision of Property Buyers: The Housing Quality, Financial Capabilities, and Government Policies Studies

Paramesran, R. (2013). The role of the banking system, Housing the Nation: Policies, Issues and Prospects (p. 137), Malaysia, Cagamas

Pembina Institute (2013). Priced Out: Understanding the factors affecting home prices in the GTA, Canada, Royal Bank of Canada

Rahadi, R. A., Sudarso, K. W., Deddy, P. K. \& Indra, B.S. (2013). Attributes Influencing Housing Product Value and Price in Jakarta Metropolitan Region. Procedia Social and Behavioural Sciences, 101(0), 368-378.

Real Estate and Housing Developers Association (REHDA) (2014). Property outlook 2014: Interview with REHDA president. REHDA, Selangor.

Sew, G. S., \& Chin, T. Y. (2000). Hillside development - Planning, Design, Constrution and Maintenace consideration. IEM Seminar on Geotechnical Engineering, Penang, 1-22

Shinde, N., \& Gawande, K. (2018). Survey on predicting property price. In 2018 International Conference on Automation and Computational Engineering (ICACE) (pp. 1-7). IEEE.

Tan, T. H. (2012). Meeting first-time buyers' housing needs and preferences in greater Kuala Lumpur. Cities, 29(6), 389-396.

Teoh, W.L. (2011). Factors affecting the preferences of residential housing in gated community.

The Edge Property (2016). Half of overhang units are homes priced at RM300,000 and below. Available at: http://www.theedgeproperty.com.my/content/half-overhangunits-are-homes-priced-rm300000-and-below. [Accessed on 15 September 2016]

Tobi, S., Fathi, M., \& Amaratunga, D. (2018). Ageing in place framework as reference guide for housing in Malaysia: Landed property. Planning Malaysia Journal of the Malaysian Institute of Planners, 16(1), 130-143.

Tonglet, M., Phillips, P. S., \& Read, A. D. (2004). Using the Theory of Planned Behaviour to investigate the determinants of recycling behaviour: a case study from Brixworth.

Zainuddin, N. (2015). Overview of Real Property Gain Tax in Malaysia. The Sixth IMFJapan High Level Tax Conference for Asian Countries

Zainun, N.Y. and Ismail, S.S. (2015). 'Low Cost Housing Demand Factors In Malaysia'. Applied Mechanic and Materials, 773, 1037-1041.

Zainun, N.Y., Rahman, I.A., \& Eftekhari, M. (2010). Forcasting low cost housing demand in Johor Bharu, Malaysia using Artificial Neural Networks (ANN). Journal of Mathematic Research. 2(1). P. 16-19

Zandi', G., Mahadevan, A., Supramaniam, L., Aslam, A., \& Theng, L. K. (2015). The economical factors affecting residential property price: The case of Penang island. International Journal of Economics and Finance, 7(12).

Zikmund, William G., Babin, Barry J., Carr, Jon C., \& Griffin, Mitch. (2010). Business Research methods (8th ed.). USA: South-Western, CenGage Learni 